community-based study. International Journal of Geriatric Psychiatry, 9, 5-10.

Murphy, E. (1983) The prognosis of depression in old age. British Journal of Psychiatry, 142, III-119.

NHS Executive (1996) NHS Psychotherapy Services in England: Review of Strategic Policy. London: Department of Health.

Ong, Y. L., Martineau, F., Lloyd, C., et al (1987) A support group for the depressed elderly. International Journal of Geriatric Psychiatry, 2, 119-123.

O'Rourke, N. \& Hadjistavropoulos, T. (1997) The relative efficacy of psychotherapy in the treatment of geriatric depression. Aging and Mental Health, I, 305-310.

Reynolds, C. F., Frank, E., Perel, J. M., et al (1999) Nortriptyline and IPT as maintenance therapies for recurrent major depression: a randomised controlled trial in patients older than 59 years. Journal of the American Medical Association, 281, 83-84.

Roth, A. D. \& Fonagy, P. (1996) What Works for Whom? A Critical Review of Psychotherapy Research New York: Guilford Press.

Shah, A. \& De, T. (1998) Suicide and the elderly, International Journal of Psychiatry Clinical Practice, 2, 3-17.

Tuma, T. A. (2000) Outcome of hospital-treated depression at 4.5 years. An elderly and a younger adult cohort compared. British Journal of Psychiatry, 176, 224-228.

S. I. Evans St Bartholomew's and Homerton Hospitals, London ECIY 7BE

\section{Medication and alcohol in nursing homes}

Furniss et al (2000) report the findings from a promising trial which addresses the inappropriate use of medication in nursing homes. They conclude that a pharmacist's review followed by a reduction in medication does not necessarily increase rates of morbidity or mortality. However, one commonly used drug that was not included in their review was alcohol.

Significant rates of alcohol misuse have been recorded in nursing home settings (Johnson, 2000), and interactions between prescribed (as well as over-the-counter) medication and alcohol pose significant risks for older people drinking unregulated amounts of alcohol. Alcohol interacts with many of the commonly prescribed medications cited in the study, especially antidepressants and sedatives. Therefore, residents in the study who drink alcohol will have benefited from the intervention of stopping medication by removing the risk of a potentially dangerous drug reaction.

As part of a survey in Bristol, I approached the managers of several residential homes to find out whether they held a policy regarding alcohol use in the home.
None of the seven homes surveyed had such a policy in place, despite some residents having alcohol problems, and it was not unusual for homes to sell alcohol on the premises, either across a bar or in a shop.

Pharmacists have a key role in advising patients of potential interactions with alcohol (Ward, 1997). The provision of clear and up-to-date information about these interactions could form part of an alcohol policy in nursing and residential homes.

Furniss, L., Burns, A., Craig, S. K. L., et al (2000) Effects of a pharmacist's medication review in nursing homes. Randomised controlled trial. British Journal of Psychiatry, I76, 563-567.

Johnson, I. (2000) Alcohol problems in old age: A review of recent epidemiological research. International Journal of Geriatric Psychiatry, in press.

Ward, M. (1997) Older People and Alcohol - A Neglected Area?, p. 63. London: Health Education Authority.

I. Johnson Cossham Hospital, Lodge Road, Kingswood, Bristol BSI5 ILF

\section{Talmudic, Koranic and other classic reports of stalking}

Kamphuis \& Emmelkamp's (2000) review on stalking gives an acute clinical perspective to the Hebrew myth of Joseph and Zuleika related in Genesis XXXIX. After being sold as a slave, Joseph became the target of his master's wife's wanton passion. $\mathrm{He}$ steadfastly rejected all her amorous advances and was eventually condemned to prison on account of her calumnies.

This archetype of stalking has many derivations in Jewish, Arabic, Syriac, Persian, Indian and medieval European lore (Rappoport, 1995). Talmudic and midrashic accounts emphasise the complex behavioural sequence of the stalker: implicit seductive manoeuvres; explicit proposals; verbal menaces; planned physical aggression; false accusations; humiliation and punishment.

Moslem tradition, based on Mohammed's twelfth sura, elaborates on the erotomanic aspects of the myth. Yusuf was also in love with Zulaikha, but had no hope of reciprocity. When Yusuf had been freed from prison and appointed in the place of his former master, he married his widowed former mistress and stalker (Weil, 1845). Islamic comments also acknowledge Zulaikha's love as her only excuse. This theme of the stalkee's irresistible charm, already explicit in the Koran, is refined by Persian poets such as Firdusi (933-1025) and especially Jami (1414-1492), whose powerful metaphor of the 'fair gazelle' applied to Yusuf conveys the ambivalence of feminine grace and quick escape (Jami, 1882). Ephrem Syrus addresses the stalker's distorted insight: "Out of love for him, I treated him unjustly; and yet he owes his present greatness to us" (Grünbaum, 1901).

Christian authors tend to draw a parallel between Joseph and the Saviour. Emphasis is therefore placed on forgiveness by the stalkee. The stalker's insight is finely verbalised in 14th-century passion plays: "Principallement une dame / Comme moy; je suis esbahye / Je considère ma follye / Mais, bref, amour me contrainct tant / Qu'il sera force que je prie / Joseph pour estre mon amant" (Anonymous, 1881). In 16th-century Yiddish dramas composed for Purim, a festival celebrating the liberation of Jews from a deadly plot, the slave's and the mistress's alienation and freedom are dialectically discussed and Joseph's stalker goes by many different names (but not Zuleika). Zuleika's syndrome is also staged with other nuances by Goethe and in a famous Broadway show. This overview reinforces Kamphuis \& Emmelkamp's view of a typical phenomenon which has remained a contemporary challenge, and also their suggestion of cultural biases in the perception of stalking.

Anonymous (188I) Le Mistère du Vieil Testament (ed. J. de Rothschild), Tome III, pp. 67-69. Paris.

Grünbaum, G. (1901) Gesammelte Aufsätze zur Sprache und Sagenkunde. Berlin.

Jami, M. N. (1882) Yusuf and Zuliaykha (trans. R. T. H. Griffith). In Oriental Series. London: Trübner.

Kamphuis, J. H. \& Emmelkamp, P. M. G. (2000)

Stalking - a contemporary challenge for forensic and clinical psychiatry. British Journal of Psychiatry, 176, 206-209.

Rappoport, A. S. (1995) Ancient Israel. Volume Two. London: Studio Editions.

Weil, G. (1845) Biblische Legenden der Muselmänner. Frankfurt am Main.

B. Dan Neurology Department, University Children's Hospital Queen Fabiola, 15 Avenue J J Crocq, B-1020 Brussels, Belgium

C. Kornreich Institute of Psychiatry, Brugmann University Hospital, Université Libre de Bruxelles, B-1020, Belgium

\section{Venlafaxine-induced painful ejaculation}

Antidepressant drugs cause a variety of sexual side-effects. Painful ejaculation is a 